\title{
SALT CONTENT OF WOMAN'S MILK IN SOME CASES IN WHICH ITS USE WAS NOT BENEFICIAL
}

BY

ANGELIA M. COURTNEY, B.A., and ALAN BROWN, M.B.

(From the Sub-Department of Pædiatrics, University of Toronto, and the Hospital for Sick Children, Toronto.)

During a period of four successive years there is a record at the Hospital for Sick Children, Toronto, of ninety infants admitted suffering from tetany in a more or less severe form. Of this number twenty had been breast-fed to date, some of the older infants taking in addition a milk dilution and sometimes cereal and biscuit. Two others of the ninety had been exclusively breastfed to within two weeks of admission, and eight more had been breast-fed for a period of six months or longer after birth, though on artificial feeding for a month or more preceding the attack. Thus one-third of the infants with tetany had been breast-fed to date or for a period of six months or more after birth. It seems not unreasonable to conclude either that the mothers' milks were abnormal in composition, or that under adverse conditions normal woman's milk does not afford sufficient protection against tetany.

It is customary when breast-fed infants are admitted to the hospital suffering from tetany, or showing marked signs of rickets without tetany, to discontinue breast feeding entirely. Since under these circumstances it is usually a simple matter to obtain a large representative sample of the mother's milk, it seemed advisable to make complete salt analyses of the milk in as many cases as possible in order to learn how nearly these milks showed values within the normal range. As far as possible the milk was collected under the supervision of a nurse in the infant ward, and in the other cases explicit directions for making the collection were given the mother. The aim was to get all the milk that could be expressed from both breasts until a total of twenty ounces or more was obtained, the period of collection not to exceed three days. Beginning and end milkings by themselves were particularly to be avoided. The samples were kept cold until collection was completed, and no milkwas used for analysis in a curdled state or when the cream could not be shaken into a homogeneous mixture with the rest of the milk.

Occasionally infants showed other symptoms than those of rickets and tetany which were assumed to be related to their being fed at the breast. This assumption was made because no other explanation was apparent and because usually the symptoms entirely disappeared when the infant was changed on to artificial feeding. In all such cases also, when practicable, collection of the mothers' milk was made for analysis. Altogether there were thus obtained for analysis seventeen milk samples from mothers of infants suffering from rickets and tetany, and thirteen from women whose milk appeared not to agree with the infants as indicated by other symptoms, such as, convulsions, not tetany, vomiting, diarrhœa, failure to gain in weight.

If the collected sample was sufficiently large, fat was estimated according to Babcock and a nitrogen separation was made in the fresh milk. The bulk 
of the collection was immediately measured and set on a steam bath to dry to constant weight. In the powdered dried milk, total ash, calcium, magnesium, phosphorus, chloride, potassium and sodium were determined according to standard gravimetric methods. The sodium and potassium separation was made by the cobaltinitrite method according to the procedure of $\mathrm{H}$. H. Green ${ }^{1}$. There has been some criticism of the cobaltinitrite determination of potassium on the ground that the precipitate of sodium potassium cobaltinitrite is not a strictly constant compound. The values obtained by this procedure are given for what they are worth, but because of their possibly questionable value there are also included in the table values for total sodium and potassium chloride as separated from the other salts before the determination of potassium was made. It must be kept in mind that these values being chlorides of the elements are large in comparison with the total ash values.

Table 1 gives the values in grammes per $100 \mathrm{c.cm}$. of milk for the salt analysis (A) of the milks of mothers of infants suffering from tetany or rickets, and (B) for the milks when the infants showed other symptoms supposedly related to the breast feeding. Table 2 was compiled from table. 1 to bring out in a more graphic way a comparison of these values with the normal averages. Values are considered average, indicated by 'ave.', if very close to those obtained for mature milk by Holt et al ${ }^{2}$. In the case of $\mathrm{CaO}$ the average was considered to run to $\cdot 043 \mathrm{grm}$. per $100 \mathrm{c.cm}$. of milk because of the somewhat lower normal values found by Burhans and Smith ${ }^{3}$ and by DeBuys and Meysenburg ${ }^{4}$, and in the case of $\mathrm{K}_{2} \mathrm{O}$ the average was extended to $\cdot 060 \mathrm{grm}$. per $100 \mathrm{c.cm}$. of milk, the value reported by Burhans and Smith. One $(+)$ and one (-) was assigned to a value lying between the average and the normal limits for each element as given in Holt's tables, with a slight extension of the lower limit for calcium and the upper for potassium. For values higher or lower than the normal limits, the number of signs indicates the degree of divergence from the normal values. This distribution of signs is arbitrary but affords an approximately accurate measure of comparison of the different milks, particularly so in respect to each element by itself.

Considering table 2 as a whole it is seen that the greatest number of values outside the normal range, with more than one $(+)$ or $(-)$, occurs in the magnesium, chloride and sodium columns. In Group (A) alone sodium, calcium and magnesium have the greatest number of divergences, while in (B) all the columns except calcium and potassium show a large proportion of the values beyond the normal range. Thus it appears from these findings that the milks taken by the infants suffering from rickets and tetany show considerably less divergence from the normal in salt content than the milks which failed to agree with the infants for various other reasons. It is perhaps significant that in the rickets and tetany Group (A) the calcium and magnesium values, especially those for calcium, were mostly in the low direction from the average, though only about one-third were actually beyond the range found for normal milks. The values for phosphorus were more in the high direction, though few were beyond the normal range. The sodium column in this group shows many very high values in marked contrast with the calcium and magnesium values. This 
is probably why the values for total salts were mostly in the normal range in this group. In Group (B) nearly all the values for total salts were higher than normal, for in Group (B) most of the abnormal values for the separate salts were in the direction of high values.

In four instances in which the milk calcium content was below the normal, values were obtained for the infants' blood calcium or phosphorus or both. In two of these both calcium and phosphorus of the blood were low, in one other calcium was low, phosphorus not being determined, and in the fourth calcium was normal but phosphorus very low, the infant in this case suffering from rickets only. In six other cases of Group (A) in which the milk calcium content was lower than the average but not beyond the normal limit, blood calcium or phosphorus or both were low.

The literature bearing upon the effect of diet upon the composition of the milk secreted was discussed in a preceding paper ${ }^{5}$ in which four of the milk samples included in those here presented were reported, and the discussion will not be taken up again now. In connection with most of these milk collections a description of the diet of the mother was obtained, particular attention being given to the quantity of the milk taken and whether adequate sources of fatsoluble and other vitamines were included. Although these reports were not altogether satisfactory, on the basis of them an attempt has been made to classify the diets of the mothers represented in Group (A) as poor, if glaringly defective in quantity of milk and vitamin supply, fair if deficient in one of these respects but not the other, and very poor when total caloric intake as wel! as quantity of milk and vitamin supply were clearly below requirement. Of these mothers whose milk calcium content was below the normal limit the diets were in two cases rated very poor, in two poor, and in two fair. In four cases in which the milk calcium content was below the average but within normal limits, the diets of the mothers were rated poor. In no case was a diet of the mothers of the infants suffering from rickets or tetany rated above fair. Curiously one of the most deficient diets reported was that of the mother indicated (Case 16) in the table, whose values for milk salts were among those the most nearly normal in the Group (A). Nursing, however, had not been so long continued as in the majority of cases in the group, the infant being only four months of age. In most of the milks of Group (A) the fat content was lower than the average, in three cases abnormally low.

The cases in Group (B) require some individual discussion. Case 18, a six weeks' old infant, had convulsions which ceased on removal from the breast, the convulsions being considered not due to tetany. The milk was abnormally low in calcium and magnesium content. Case 19 also had convulsions not due to tetany, calcium content of the blood serum being normal. There was also an acute infection in this case. The concentration of milk salts was almost normal. Case 27, a two weeks' old infant with a temperature unaccounted for, was taking a milk almost lacking in magnesium and abnormally high in total salts, sodium and potassium. Case 28 , an infant who was vomiting 
when taking mother's milk, recovered when changed to artificial feeding. This milk had a magnesium and sodium content lower than normal, that of potassium higher. Case 2.), a 3 months' old infant with eczema, was taking a milk abnormally high in total salts, magnesium, sodium and chloride. Cases 23, 20 , and 22 designate milks of wet nurses supplying premature infants in hospital wards. The infants were not thriving or showing the progress expected under the circumstances. Analyses were not complete for two of these milks, but the only outstanding abnormalities found were a very high calcium content in one, and very high phosphorus content in another. With a three months' old infant not thriving on mother's milk (Case 24), the low fat content seemed to be sufficient reason for the failure to gain in weight. There was also a decidedly abnormal salt content, phosphorus, scdium and chloride all being extremely high. The mother took exceptionally large amounts of table salt with her food. In three other cases (21, 29 and 30), the infants had ceased to gain and suffered from diarrhœa while taking mother's milk, and improved when removed from the breast. All these milks had phenonemally high sodium, potassium, chloride and total salt content. In two cases sodium ard potassium were not determined but the great concentration of these elements can be inferred from the other values. In the milk highest in sodium and potassium chloride, calcium and phosphorus concentration was extremely low. In one of these three cases (No. 29), the mother took unusually large amounts of table salt with her food. There was no report on this point with the other two.

\section{Summary.}

1. Analyses to determine the content of the various salts were made in thirty samples of woman's milk which appeared to have an unfavourable effect upon the infant or infants taking it: in seventeen samples in cases in which the infants were suffering from rickets and tetany and in thirteen in which there were other unfavourable symptoms supposedly due to the breast feeding.

2. The milks in the tetany and rickets group showed a tendency to be low in calcium and magnesium, high in sodium content. In the other group the tendency was to be high in total salt, sodium, potassium and chloride, though there were some markedly abnormal values found in respect to all the salts determined. Only two milks of this group showed no striking abnormality.

3. Whenever the blood calcium and phosphorus were determined and one or both were found to be lower than the normal, the calcium content of the milk was either lower than the normal limit or at least lower than the normal average.

4. The diets of all but one of the mothers represented in the tetany and rickets group were looked into and all were found to be more or less deficient in one or more of the following points :-total quantity of milk, sources of vitamines, especially the fat soluble, and total caloric value of intake. Three were deficient in all three respects. 
5. In the group in which the infants showed unfavourable symptoms other than those of tetany and rickets, with two exceptions the milk analyses showed abnormal values for two or more salts, in many cases extremely abnormal values. Two of the mothers were accustomed to taking large amounts of table salt with their food.

\section{REFERENCES.}

1. Green, H. H., Biochem, J., Cambridge, 1912, VI, 69.

2. Holt, L. E., Courtney, A. M., \& Fales, H. L., Amer. J. Dis. Child., Chic., 1915, X, 229.

3. Burhans, G. W., \& Smith, D. N., Loc. cit., 1923, XXVI, 303.

4. DeBuys, L. R., \& Von Meysenburg, L., Loc. cit., 1924, XXVII, 438.

5. Courtney, A. M., Loc. cit., 1923, XXVI, 534. 
TABLE 1.

Salt content of abNormal milks: grammes PER 100 c.cm. Milk.

\begin{tabular}{l|l|l|l|l|l|l|l|l|l|l|l|l|l}
\hline $\begin{array}{l}\text { Case } \\
\text { No. }\end{array}$ & Name & Month & $\begin{array}{c}\text { Total } \\
\text { solids }\end{array}$ & Fat Nitrogen & $\mathrm{CaO}$ & $\mathrm{MgO}$ & $\mathrm{P}_{2} \mathrm{O}_{5}$ & $\mathrm{Cl}$ & $\mathrm{Na}_{2} \mathrm{O}$ & $\begin{array}{c}\mathrm{K}_{2} \mathrm{O} \\
\mathrm{Na} \& \mathrm{~K} \\
\text { as } \\
\text { chlorides }\end{array}$ & $\begin{array}{c}\mathrm{Total} \\
\text { Ash }\end{array}$ \\
\hline
\end{tabular}

Group A.

\begin{tabular}{|c|c|c|c|c|c|c|c|c|c|c|c|c|c|}
\hline 1 & Bak. & Mar. & $13 \cdot 17$ & - & - & .0363 & .0056 & $\cdot 0464$ & $\cdot 0392$ & .0145 & .0801 & $\cdot 1545$ & .2343 \\
\hline 2 & Ro. & Mar. & $11 \cdot 54$ & $2 \cdot 5$ & $\cdot 1551$ & .0349 & .0102 & .0618 & .0346 & .0365 & .0324 & $\cdot 1203$ & $\cdot 1830$ \\
\hline 3 & Wa. & Apr. & $10 \cdot 68$ & $3 \cdot 75$ & $\cdot 1185$ & .0317 & .0041 & .0375 & 0350 & .0156 & .0537 & $\cdot 1148$ & $\cdot 1719$ \\
\hline 4 & He. & Jan. & $11 \cdot 49$ & $2 \cdot 7$ & $\cdot 1979$ & .0295 & .0056 & .0431 & .0429 & .0467 & .0705 & $\cdot 2000$ & .2635 \\
\hline 5 & Ca. & Mar. & $11 \cdot 51$ & $4 \cdot 4$ & - & .0367 & .0067 & $\cdot 0541$ & .0379 & .0161 & .0723 & $\cdot 1450$ & $\cdot 2076$ \\
\hline 6 & Ha. & Mar. & $9 \cdot 90$ & $1 \cdot 5$ & $\cdot 1261$ & .0331 & .0070 & $\cdot 0357$ & $\cdot 0494$ & $\cdot 0281$ & $\cdot 0538$ & $\cdot 1384$ & .2067 \\
\hline 7 & Ste. & Mar. & $12 \cdot 94$ & - & - & $\cdot 0384$ & .0064 & - & - & .0355 & $\cdot 0719$ & $\cdot 1811$ & $\cdot 2711$ \\
\hline 8 & Mar. & Feb. & $12 \cdot 72$ & $3 \cdot 5$ & $\cdot 1694$ & .0276 & 一 & .0584 & $\cdot 0290$ & .0166 & $\cdot 0979$ & $\cdot 1866$ & $\cdot 1483$ \\
\hline 9 & Mi. & Jan. & $11 \cdot 70$ & $3 \cdot 4$ & $\cdot 1379$ & .0285 & .0029 & $\cdot 0291$ & $\cdot 0340$ & $\cdot 0100$ & .0861 & $\cdot 1556$ & $\cdot 2340$ \\
\hline 10 & Hun. & Jan. & $11 \cdot 26$ & $2 \cdot 0$ & $\cdot 1876$ & .0378 & $\cdot 0022$ & .0345 & $\cdot 0246$ & .0086 & .0665 & $\cdot 1217$ & $\cdot 1914$ \\
\hline 11 & Hut. & Feb. & $12 \cdot 32$ & $2 \cdot 65$ & $\cdot 2184$ & .0395 & .0075 & .0284 & $\cdot 0411$ & .0260 & $\cdot 0732$ & $\cdot 1653$ & $\cdot 2489$ \\
\hline 12 & Bi. & Mar. & $13 \cdot 51$ & $4 \cdot 3$ & $\cdot 1876$ & $\cdot 0431$ & .0040 & $\cdot 0352$ & $\cdot 0330$ & $\cdot 0308$ & $\cdot 0572$ & $\cdot 1489$ & $\cdot 2125$ \\
\hline 13 & Boe & June & $12 \cdot 36$ & - & - & $\cdot 0290$ & $\cdot 0074$ & $\cdot 0258$ & .0475 & $\cdot 0284$ & .0618 & $\cdot 1517$ & $\cdot 1928$ \\
\hline 14 & Ch. & Feb. & $10 \cdot 43$ & - & - & $\cdot 0290$ & .0035 & .0418 & .0309 & .0195 & $\cdot 0584$ & $\cdot 1295$ & $\cdot 1823$ \\
\hline 15 & Mat. & Feb. & $13 \cdot 0$ & $3 \cdot 9$ & $\cdot 1838$ & $\cdot 0384$ & .0069 & .0466 & $\cdot 0394$ & .0192 & .0644 & $\cdot 1384$ & $\cdot 2124$ \\
\hline 16 & So. & Dec. & $11 \cdot 92$ & - & - & $\cdot 0498$ & .0076 & $\cdot 0337$ & .0449 & .0068 & .0254 & .0532 & $\cdot 2410$ \\
\hline 17 & DeR & Mar. & $10 \cdot 25$ & $1 \cdot 4$ & $\cdot 1701$ & $\cdot 0343$ & $\cdot 0045$ & $\cdot 0315$ & .0508 & .0336 & $\cdot 0646$ & $\cdot 1660$ & $\cdot 2325$ \\
\hline \multicolumn{10}{|c|}{ Grove B. } & \\
\hline 18 & Ja. & Feb. & $13 \cdot 59$ & - & - & $\cdot 0150$ & .0009 & $\cdot 0625$ & $\cdot 0462$ & $\cdot 0138$ & $\cdot 0658$ & $\cdot 1304$ & $\cdot 2347$ \\
\hline 19 & Bo. & Feb. & $10 \cdot 39$ & $1 \cdot 3$ & $\cdot 1743$ & .0540 & .0064 & .0264 & .0469 & .0227 & $\cdot 0533$ & $\cdot 1275$ & $\cdot 2258$ \\
\hline 20 & Sta. & June & $12 \cdot 91$ & $3 \cdot 5$ & $\cdot 1680$ & .0417 & .0045 & $\cdot 0682$ & $\cdot 0239$ & .0161 & .0528 & $\cdot 1141$ & $\cdot 1940$ \\
\hline 21 & $\mathrm{Au}$. & Nov. & $12 \cdot 90$ & $3 \cdot 5$ & $\cdot 3024$ & .0633 & .0076 & $\cdot 0625$ & .0697 & .0355 & $\cdot 1079$ & $\cdot 2383$ & $\cdot 3477$ \\
\hline 22 & Mas. & Sept. & $11 \cdot 56$ & - & $\cdot 1736$ & $\cdot 1003$ & $\cdot 0117$ & $\cdot 0540$ & - & - & 一 & 一 & $\cdot 2250$ \\
\hline 23 & I.W. & Feb. & $12 \cdot 85$ & - & $\cdot 1799$ & .0345 & $\cdot 0057$ & - & 一 & - & 一 & 一 & $\cdot 1719$ \\
\hline 24 & Be. & May & $9 \cdot 77$ & $1 \cdot 1$ & $\cdot 1477$ & $\cdot 0463$ & .0051 & $\cdot 0741$ & $\cdot 0674$ & $\cdot 0283$ & .0607 & $\cdot 1498$ & $\cdot 2463$ \\
\hline 25 & Bar. & Mar. & $13 \cdot 57$ & $3 \cdot 9$ & $\cdot 2342$ & $\cdot 0412$ & $\cdot 0148$ & .0414 & .0554 & $\cdot 0357$ & $\cdot 0622$ & $\cdot 1662$ & $\cdot 2504$ \\
\hline 26 & Ho. & Nov. & 9.92 & $1 \cdot 2$ & $\cdot 1667$ & .0356 & .0038 & .0243 & $\cdot 0546$ & $\cdot 0436$ & $\cdot 0559$ & $\cdot 1711$ & $\cdot 2273$ \\
\hline 27 & Sc. & Nov. & $13 \cdot 30$ & $3 \cdot 7$ & $\cdot 2583$ & $\cdot 0356$ & $\cdot 0002$ & $\cdot 0437$ & .0413 & .0316 & .0841 & $\cdot 1931$ & $\cdot 2547$ \\
\hline 28 & Tu. & Oct. & $12 \cdot 75$ & $3 \cdot 2$ & $\cdot 1774$ & .0409 & .0040 & $\cdot 0316$ & .0317 & $\cdot 0060$ & .0925 & $\cdot 1582$ & .2270 \\
\hline 29 & Gi. & Jan. & 8.95 & 0.9 & $\cdot 1834$ & $\cdot 0412$ & - & .0161 & $\cdot 1488$ & - & - & - & $\cdot 3881$ \\
\hline 30 & Sm. & Oct. & $7 \cdot 46$ & $2 \cdot 2$ & $\cdot 1995$ & .0095 & .0055 & .0142 & $\cdot 2566$ & - & - & - & 5607 \\
\hline
\end{tabular}


TABLE 2.

Relation to noRmal values.

\begin{tabular}{|c|c|c|c|c|c|c|c|c|c|c|c|}
\hline $\begin{array}{c}\text { Case } \\
\text { No. } \\
\end{array}$ & Name & $\begin{array}{c}\text { Age } \\
(\mathrm{mths})\end{array}$ & Symptoms & $\begin{array}{c}\text { Serum Ca. } \\
\text { and } P .\end{array}$ & $\mathrm{CaO}$ & $\mathrm{MgO}$ & $\mathrm{P}_{2} \mathrm{O}_{5}$ & $\mathrm{Cl}$ & $\mathrm{Na}_{2} \mathrm{O}$ & $\mathrm{K}_{2} \mathrm{O}$ & $\begin{array}{l}\text { Total } \\
\text { solids }\end{array}$ \\
\hline 1 & Bak. & 7 & $\begin{array}{l}\text { Tetany, and sl. } \\
\text { Rickets. }\end{array}$ & $\mathrm{Ca} 9 \cdot 7$ & - & - & + & ave. & ave. & $t+$ & + \\
\hline 2 & Ro. & 9 & $\begin{array}{l}\text { Tetany, and sl. } \\
\text { Rickets. }\end{array}$ & $\begin{array}{l}\mathrm{Ca} 5 \cdot 6 \\
\text { P. } 3 \cdot 3\end{array}$ & - & + & ++ & ave. & $+t+t$ & -- & ave. \\
\hline 3 & Wa. & $8 \frac{1}{2}$ & Tetany. & & -- & -- & ave. & ave. & ave. & - & - \\
\hline 4 & $\mathrm{He}$ & 7 & $\begin{array}{l}\text { Tetany. } \\
\text { Rickets. }\end{array}$ & $\mathrm{Ca} 5 \cdot 0$ & -- & - & + & + & +++++ & + & ++ \\
\hline 5 & Ca. & 12 & $\begin{array}{l}\text { Tetany. } \\
\text { Rickets. }\end{array}$ & $\begin{array}{c}\mathrm{Ca} 5 \cdot 2 \\
\mathrm{P} 6 \cdot 8\end{array}$ & - & - & ++ & ave. & ave. & + & ave. \\
\hline 6 & Ha. & 7 & $\begin{array}{l}\text { Tetany. } \\
\text { Rickets. }\end{array}$ & $\begin{array}{c}\mathrm{Ca} 4 \cdot 6 \\
\mathrm{P} 7 \cdot 0\end{array}$ & - & - & ave. & ++ & +++ & - & ave. \\
\hline 7 & Ste. & $9 \frac{1}{2}$ & $\begin{array}{l}\text { Tetany. } \\
\text { Rickets. }\end{array}$ & $\begin{array}{c}\text { Ca } 7 \cdot 8 \\
\text { P } 4 \cdot 4\end{array}$ & - & - & (n.e.) & (n.e.) & ++++ & + & ++ \\
\hline 8 & Mar. & 4 & $\begin{array}{l}\text { Tetany. } \\
\text { Rickets. }\end{array}$ & & -- & (n.e.) & ++ & - & ave. & $+t+$ & -- \\
\hline 9 & Mi. & $7 \frac{1}{2}$ & $\begin{array}{l}\text { Tetany. } \\
\text { Rickets. }\end{array}$ & $\begin{array}{c}\mathrm{Ca} 6 \cdot 3 \\
\mathrm{P} \mathbf{3} \cdot 5\end{array}$ & -- & --- & - & ave. & - & ++ & + \\
\hline 10 & Hun. & 4 & $\begin{array}{l}\text { Tetany. } \\
\text { Rickets. }\end{array}$ & $\begin{array}{c}\mathrm{Ca} 6 \cdot 2 \\
\mathrm{P} 6 \cdot 4\end{array}$ & - & --- & ave. & -- & - & + & ave. \\
\hline 11 & Hut. & 2 & $\begin{array}{l}\text { Tetany. } \\
\text { Rickets. }\end{array}$ & & - & ave. & - & + & ++ & + & ++ \\
\hline 12 & Bi. & 3 & $\begin{array}{l}\text { Prem. } \\
\text { Tet. Rickets. }\end{array}$ & $\begin{array}{l}\mathrm{Ca} 7 \cdot 6 \\
\text { P } 3 \cdot 0\end{array}$ & ave. & -- & ave. & - & $+t+$ & ave. & ave. \\
\hline 13 & Boe & 6 & $\begin{array}{l}\text { Abscess. } \\
\text { Rickets. }\end{array}$ & $\begin{array}{c}\mathrm{Ca} 9 \cdot 2 \\
\mathrm{P} 2 \cdot 8\end{array}$ & -- & ave. & - & $+t$ & $+t+$ & + & ave. \\
\hline 14 & $\begin{array}{l}\text { Ch. } \\
\text { Twins }\end{array}$ & 4 & $\begin{array}{l}\text { Anæmia. } \\
\text { Rickets. }\end{array}$ & $\begin{array}{l}\mathrm{Ca} 9 \cdot 7-9 \cdot 2 \\
\mathrm{P} 4 \cdot 6-2 \cdot 6\end{array}$ & -- & -- & + & - & + & ave. & ave. \\
\hline is & Mat. & 8 & Rickets. & $\begin{array}{c}\mathrm{Ca} 6 \cdot 8 \\
\mathrm{P} 2 \cdot 0\end{array}$ & - & - & + & ave. & + & + & ave. \\
\hline
\end{tabular}

n.e. $=$ not estimated: 
TABLE 2-Continued.

RELATION TO NOKMAL VALUES.

\begin{tabular}{|c|c|c|c|c|c|c|c|c|c|c|c|}
\hline $\begin{array}{l}\text { Case } \\
\text { No. }\end{array}$ & Name & $\begin{array}{c}\text { Age } \\
\text { (mths) }\end{array}$ & Symptoms & $\begin{array}{l}\text { Serum Ca. } \\
\text { and P. }\end{array}$ & $\mathrm{CaO}$ & $\mathrm{MgO}$ & $\mathrm{P}_{2} \mathrm{O}_{5}$ & $\mathrm{Cl}$ & $\mathrm{Na}_{2} \mathrm{O}$ & $\mathrm{K}_{2} \mathrm{O}$ & $\begin{array}{l}\text { Total } \\
\text { Solids }\end{array}$ \\
\hline 16 & So. & 4 & Rickets. & & + & ave. & ave. & + & -- & --- & + \\
\hline 17 & DeR & 5 & Rickets. & & - & -- & - & ++ & ++++ & + & + \\
\hline 18 & Ja. & $1 \frac{1}{2}$ & $\begin{array}{l}\text { Convulsions and } \\
\text { vomiting ceasing } \\
\text { on changed food. }\end{array}$ & & $---\cdots$ & $\begin{array}{l}--- \\
---\end{array}$ & ++ & ++ & ave. & + & 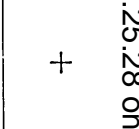 \\
\hline 19 & Bo. & 7 & $\begin{array}{l}\text { Convulsions not } \\
\text { tetany. }\end{array}$ & Ca normal & + & - & - & ++ & + & - & + \\
\hline 20 & Sta. & 2 & $\begin{array}{l}\text { Premature. Infants } \\
\text { not thriving. }\end{array}$ & & - & -- & +++ & -- & ave. & - & ave. $\frac{\bar{g}}{c}$ \\
\hline 21 & $\mathrm{Au}$. & & $\begin{array}{c}\text { Premature. } \\
\text { Diarrhœea. }\end{array}$ & & +++ & ave. & ++ & +++ & $\begin{array}{l}++ \\
++\end{array}$ & ++++ & $++++\frac{c}{\varepsilon}$ \\
\hline 22 & Mas. & $3 \frac{1}{2}$ & $\begin{array}{l}\text { Infant not thriv- } \\
\text { ing. }\end{array}$ & & $\begin{array}{c}+++ \\
++\end{array}$ & ++ & $t+$ & (n.e.) & (n.e.) & (n.e.) & + \\
\hline 23 & I.W. & & $\begin{array}{l}\text { (Composite) Infants } \\
\text { not thriving). }\end{array}$ & & - & - & (n.e.) & (n.e.) & (n.e.) & (n.e.) & - \\
\hline 24 & Be. & 3 & Inf. not thriving. & Ca normal & ave. & -- & $\begin{array}{l}++ \\
++\end{array}$ & +++ & +++ & ave. & 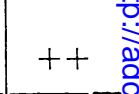 \\
\hline 25 & Bar. & 3 & $\begin{array}{l}\text { Pyloric spasm. } \\
\text { Slight eczema. }\end{array}$ & & - & ++++ & + & ++ & $\begin{array}{l}++ \\
++\end{array}$ & + & ++ \\
\hline 26 & Ho. & & $\begin{array}{l}\text { Anæmia. } \\
\text { Inf. not thriving. }\end{array}$ & & - & -- & - & ++ & $\begin{array}{c}+++ \\
++\end{array}$ & ave. & + \\
\hline 27 & Sc. & $\frac{1}{2}$ & $\begin{array}{l}\text { Unaccounted for } \\
\text { temperature. }\end{array}$ & & - & $\begin{array}{l}---- \\
----\end{array}$ & + & + & +++ & ++ & ++ \\
\hline 28 & Tu. & & $\begin{array}{l}\text { Vomiting ceasing } \\
\text { on changed food. }\end{array}$ & & - & -- & - & - & -- & +++ & + \\
\hline 29 & Gi. & 4 & Diarrhœa. & & - & (n.e.) & --- & $\begin{array}{c}+++ \\
++\end{array}$ & (n.e.) & (n.e.) & $\begin{array}{c}+++\stackrel{0}{\stackrel{C}{\mathbb{D}}} \\
++\stackrel{\mathscr{A}}{?}\end{array}$ \\
\hline 30 & Sm. & 13 & $\begin{array}{l}\text { Infant not thriv- } \\
\text { ing. }\end{array}$ & & $\begin{array}{l}--- \\
---\end{array}$ & - & --- & $\begin{array}{l}++++ \\
++++\end{array}$ & (n.e.) & (n.e.) & $\begin{array}{l}++++0 \\
++++\mathbb{\infty} \\
+\end{array}$ \\
\hline \multicolumn{12}{|c|}{ n.e. $=$ not estimated. } \\
\hline
\end{tabular}

